\title{
Research Interests and Fields
}

\author{
Mihály Sárkány \\ Institute of Ethnology, RCH, Hungarian Academy of Sciences, Budapest
}

\begin{abstract}
Depending on the problem, various methods can be justified for obtaining data in ethnographic research. Narrower interests can be served using simpler, formal methods, while lesser-known, broader connections can be investigated using a more open and diversified approach. Most ethnographic data are obtained in the field. However, it is proper fieldwork - which involves being immersed in a network of human relations and the communal life of the people being studied over a longer period of time - as opposed to short-term methods of gathering information that provides the opportunity to explore and explain the relationships and contexts of sociocultural phenomena that have yet to be identified. All types of fieldwork require the leavening effect of theoretical considerations, and even intensive fieldwork can and should be combined with data from other sources (e.g., historical or statistical), if possible, in order to enhance the validity of the interpretations. The author demonstrates these opportunities from his own practice: gathering data for the Atlas of Hungarian Folk Culture in a variety of localities; participating in a team undertaking a community study of Varsány, a village in Northern Hungary, which became long-term field research; and carrying out fieldwork in Rititi, a Kikuyu village in Kenya, to investigate coffee production. The analysis takes into account the interests and length of the research, the techniques applied, the position of the researcher in the studied communities, and his relationship with their members, including social distance, both during the fieldwork and through subsequent contact with them.
\end{abstract}

Keywords: Aims, length and techniques of field research, social involvement and distance, methods and relevance

Like many other sciences, sociocultural anthropology (ethnography, ethnology, folklore) relies on and interprets data collected during fieldwork. In the case of sociocultural anthropology, however, the "field" is not a visible landscape or a site of uncoverable finds, but, as in sociology and later sociography, it comprises and consists of people who 
are connected with one another through different forms of organization. ${ }^{1}$ Visual and aural experience provide the starting points for the interpretations - that is, for the organization of the data according to different potential research interests (BARABÁs 1990), and thus for the exploration of relationships, which have resulted in the emergence of traditions of the science in keeping with various theories. Visual and aural experience are born out of, and are about, human situations, of which Simone de Beauvoir wrote so aptly: "Every human situation can be viewed from without - seen from the point of view of an outsider - or from within, insofar as the subject assumes and at the same time transcends it" (BEAUVOIR 1972:16). Ethnographic-anthropological collection of data moves between these extrinsic-intimate extremes, almost never reaching the two endpoints of an imagined continuum, but tending towards one of them.

Based on my own experiences, I attempt to illustrate these possibilities with research in three types of fields that differ in terms of the goals and duration of the research, the research techniques applied, and the social distance between the researcher and those being investigated, including remaining in contact upon returning from fieldwork.

\section{ATLAS OF HUNGARIAN FOLK CULTURE}

I first undertook field research during my university studies, starting in 1963, initially with fellow students and then on my own, for the Atlas of Hungarian Folk Culture (BARABÁs 1987-1992), which involved the collection of data for part II in Ipolytölgyes and Kiskunfélegyháza, and then for the entire atlas in Füzesgyarmat, Felsőtárkány and Csákberény. Later, I took part in supplementary collection of data in many other places, up to 1971. During the collection of data for the complete atlas, I stayed at a site for anywhere between 8 and 14 days. As the process of research for the Atlas of Hungarian Folk Culture is well documented (PALÁDI-Kovács 1996:201-209; 2017), I will only write briefly about my relevant experience from a personal perspective.

Both in retrospect as well as at the time, I consider and considered this work to be a great practical experience towards becoming an ethnographer.

A wide range of well-thought-out topics transformed into a set of detailed questions made it easier for the beginner, the student "researcher", to ask questions that were of interest to those surveyed, and to obtain an overview of many areas of culture in the given location in a relatively short time. The requirements set out in the manual on collecting data (BARABÁs et al. 1959) resulted in an orderliness of knowledge concerning certain cultural traits, due to the need to determine the temporal dimensions, variations and frequency of their presence, and, importantly, due to the need for accurate documentation, to the extent of determining the angle of pictures taken of houses, women's topknots, and kerchiefs, etc. In this comparative research, I believe that we managed to satisfy the

\footnotetext{
${ }^{1}$ However, unlike ethnography (MÉSZÁros - VARGYAS 2016:11), during the reorganization of sociology in Hungary in the 1960s that followed its elimination in 1949, among the first actions was the publication of a concise work that provided high-level guidance on methods of collecting data and their epistemological functions (Cseh-Szombathy - Ferge 1968). It should be noted that in sociology, fieldwork involving informal interviews, personal conversations and participant observation is becoming increasingly practiced (NÉMETH 2015).
} 
requirement formulated by Graebner in 1911, that "the precondition of every scientific work is reliable research material" (GRAEBNER 1911:7), the compilation of which is ultimately intended to "provide a foundation" for "the clarification of ethnic and culturalhistorical processes" (BARABÁs 1963:47). I would also highlight the exploratory nature of the work, since this corpus of material did not contain an inherent explanation of the spatial division and distribution of the individual cultural elements: this had to be attempted and achieved using other knowledge. An unskilled field worker obviously did not have the insight into considerations of this kind that later processors of the data did, and his activity ended with the recording of data.

For such data recording, little effort is required to establish the appropriate human situation, for which Jenő Barabás gave important guidance, providing advice even on the forms of greeting, introducing oneself, and explaining the goal of the visit. In other words, the researcher arrives at the site as a stranger, and most likely leaves as one.

Keep in mind that the ethnographer is always a stranger in the beginning. A person who comes from far away, from another world (from a city, from another country, or another continent), who is interested in things that are rarely of interest to outsiders, with whom discussion is not uncomfortable but sometimes even interesting to his conversation partners. In addition, the researcher looks different, wears slightly different clothes, sometimes has a different skin color, and even if he or she speaks the same language, they speak it differently, with a different accent, using different expressions, not to mention the possibility of a different language. However, the main difference does not lie here, but rather in the fact that the researchers are devoting their time, and are even apparently being paid, to do something not considered as labour by those whom they are interviewing, who typically make a living doing hard, physical work. One of the most important elements of their work is thus to establish contact by bridging this gap, and it always amazed me how many of the interviewees contributed to this bridging from their side through tactful empathy.

There are, of course, situations in which the researcher might like to maintain a little more distance, such as at one of the sites, which I prefer not to name, where the entire family that I was living with, including the little girls, gathered around me in the kitchen to see how I washed up in a basin on a Sunday morning. By contrast, in the Kikuya village of Rititi, Kenyua, the oldest brother in the family with whom I was living, knocked together a bathroom for me behind the house using slats covered with flattened Blue Bond margarine cans, so that I could wash up quietly, just as the members of the family did in the evening after dark, without disturbing each other, but they realized that my white skin would glow even then.

But to return to the collection of data for the Atlas of Hungarian Folk Culture: the set of prescribed questions and the position of a stranger did not mean that it was impossible to obtain additional information during collection of data beyond the targeted facts. Thus, in the way I was provided with information about earlier or still visible cultural elements, value judgments were also sometimes included, allowing the researcher to sense the inhabitants' relationship with their fading culture. By his mere presence, the researcher was able to gain experience of personal sympathies, dislikes and behavioural patterns. There were also, of course, non-targeted communication situations of the "small talk" type (DRIESSEN - JANSEN 2013), though still of great relevance. To recall just one such occasion: in Csákberény, in 1966, Lajos László, who was over 80, showed me 
his stable, which stood completely empty as all his livestock had had to be transferred to the production cooperative. With tears in his eyes, he simply said: "That is what I have worked for all my life." This sentence added nothing to the collection work for the atlas, and I did no other research in Csákberény in which it would have been of any significance. However, when I later carried out studies and thought and wrote about the consequences of the socialist transformation of agriculture between 1958 and 1962 - which in terms of boosting agriculture and improving living conditions for the majority of the people living in villages in Hungary I considered a success in the given historical circumstances, and still think so retrospectively - this sentence always rang in my ears, reminding me of the personal losses that many suffered. This is one of the reasons why I attempted to document how socioeconomic changes can affect different age groups in different ways (SÁRKÁNY 2016:255-256, 304-308).

I must say that I indeed departed from the Atlas sites more or less as a stranger, but one who nonetheless left some traces of memories behind. This became apparent in Csákberény, thanks to István Sántha, who copied my entire collection of materials, including photos, onto a $\mathrm{CD}$, which he took to the village where he currently lives with his family. He presented the $\mathrm{CD}$ at the local cultural centre and invited me to talk about my earlier work. The large number of participants and their many questions indicated how concerned the local people were about the data collected about and from them, including the presentation of long-forgotten customs. This made it clear that returning the knowledge gained from forebears to their descendants was more than the transmission of knowledge; it meant the recovery of values for them, which makes the Atlas of Hungarian Folk Culture even more precious to me, beyond its obvious scientific value.

\section{VARSÁNY}

The second research site in consideration is Varsány in Northern Hungary, where I carried out fieldwork between 1971 and 1975, and again between 2000 and 2005, on both occasions with several people, but sometimes staying alone in the village. The aim of the research during the first period was to describe the socialist transformation of the village in a community study, for which the members of the team were thoroughly prepared by studying and discussing works written on Western European communities in the previous decades. This is how the concept emerged that the task is not to grasp a community as an object that can be distinguished from other, similar units, but rather to describe and interpret interrelated, pervasive social processes within a social community that can be considered as an open system (BELL - NewBy 1971:58) - that is, the local level should be observed within the country as its social environment.

During the second period, however, the social and cultural changes in the market economy based on private ownership in the context of a multi-party democracy were at the forefront of the investigation, which also used the community study methodology.

To further the team efforts, we rented a house in both periods, on both occasions the houses of widows who were well informed about the village, and who were in a way fountainheads of knowledge, although they differed markedly in terms of both their social position and their personality. During the first study, we stayed with the widow of a former big landowner who was in her late sixties, while during the second study 
we stayed with a widow in her early sixties who belonged to a family that owned far less land, who spent most of her time as a (now retired) member of a cooperative. It was helpful for the team that, during the first period of research, a family datasheet was compiled for all villagers over the age of fifteen, which included data on biography and descent, ownership, and artifacts of modern life.

In Varsány, where each participating researcher began by formulating their own research question, Malinowski's statement - "the more problems... [the researcher] brings with him into the field, the more he is in the habit of moulding his theories according to the facts..." (MALINOWSKI 1922:9) - was applied, as demonstrated by the fact that the individual topics were processed according to different theoretical incentives, and even the temporal boundaries differed.

Needless to say, I did not live in Varsány permanently during this long period, which would hardly have been tolerated by my wife during the first study period. Instead, the on-site fieldwork comprised several stays of one or several weeks, or sometimes a month, during which I was involved from the planning stage to completion in both cases, and in the second period also as an organizer. ${ }^{2}$ In what follows, I talk only about my own research.

My topic was the examination of the relationship between the economy and social stratification during both periods - that is, the description and interpretation of social processes: a typical area of research in social anthropology. This meant that one of the goals was the investigation of hard facts, although alongside this was the examination of the way in which those involved form their economic strategies and make decisions, and how they classify and divide society into strata - that is, how they see it from within.

This resulted in the use of different techniques of data collection. Statistical data and historical sources played a role, as did the family datasheets that were compiled by the research team with the involvement of university students. The use of these sources meant, on the one hand, that the material collected using participant observation and interviews acquired a historical dimension, making it possible to create a processual model during the first phase of the study; while in the second period, the directions of change were more diverse and less clear (SÁRKÁNY 2016:257-260, 279-290). On the other hand, in addition to the mutual projection of the information obtained from observations and interviews, the inclusion of historical sources amplified the tools, which increased the opportunities to obtain a research-based description of reality.

At the start of the research, I was a stranger, and I moved on from this status to become an acknowledged stranger. This distinction is nicely illustrated by research that was carried out simultaneously in the village by the Tömegkommunikációs Kutatóközpont (Mass Communication Research Center) during our research period, with the aim of exploring historical consciousness, which led to significant frustration. The research revealed a significant lack of knowledge, which the locals communicated as a consequence of being questioned brusquely and with impatience, which is why the results were so poor, which made them feel ashamed. Thus, compared with those who questioned them in such a

\footnotetext{
${ }^{2}$ The results of the research in Varsány can be found in the following publications: BIRó 2006; BoDROGI 1978; F. Nagy 1987; Gergely 2000; Hann - SÁRKÁny 2003; Hollos - Maday 1983:25-68, 225-300; Hoppál 1977; Jávor 1998, 2004, 2006, 2007; Kardos 2005; MÁTÉ 2004; SÁrKÁNY 1989, 2005, 2013, 2016:211-313; SzABó 2006a, 2006b.
} 
way, those of us carrying out ethnographic research became acknowledged strangers, as opposed to mere strangers in the derogatory sense of the word.

In another incident, I was obliged to restore my own reputation. On one occasion, I was invited by a Gypsy family to Sunday lunch, and I naturally turned up, taking with me the usual gift, a bottle of wine. I enjoyed a nice meal, but this gave rise to a rumor in the village, as it was such an unusual thing to happen. It took about two weeks before the aversion shown towards me by Hungarian families ended. From this, I learned the old lesson that "In fieldwork, one soon realizes that antagonism and solidary behavior, as well as discourses about enmities and solidarity, depend upon the different positions and interests of people." (WOLF 2001:57). In other words, in a given situation, it is almost impossible for the same person to carry out research simultaneously in the Hungarian and Gypsy parts of a village if he is hoping to build a relationship of familiarity. For the research after 2001, I therefore invited Ferenc Kardos, who did a highly valuable job among the Gypsy population in the village (KARDOs 2005).

In order to get to know the local conditions and relationships as fully as possible, I tried to establish genuine friendships with representatives from different social layers and occupations, and sometimes even joined them in their fun. Some of these instrumental friendships also had an emotional content (Wolf 2001:174-175), which made it easier to rekindle the friendship after 30 years, during the follow-up research. I found that frequent meetings with friends, meaningful conversations, occasional work together, or the work I did for the old village school headmaster, were almost more important than the length of time spent in the field. At the time, in 1975, I asked my friends to read the study I was then writing, and I received some very instructive feedback from them. However, the nature of our integration was ultimately justified by our results, the studies that were written and that were of interest to the people of Varsány, which is how I, along with Katalin Gergely, who undertook research on clothing during the first research period (Bodrogi 1978:201-275), came to be elected as Honorable People of Varsány (together with Béla Pálmány, the historian who contributed to our volume (BoDrogi 1978:13-61) and had family ties there), as I learned from the July 26, 2003 edition of the local newspaper.

However, even after long fieldwork and close contacts, it does not follow that I found out everything of importance. In the first study period, everyone spoke reluctantly about the president of the local Földigénylő Bizottság (Land Claims Committee) of 1945, whose activities I learned about from court documents following the redistribution of land (SÁRKÁNY 1989:122). During the second study period, in 2001, I learned from someone from Nógrádsipek (thus not from Varsány, but from the neighbouring village), whom I met only once, that a well-known person who had since died and who had commuted to Budapest and with whom I had met on several occasions had been part of the military contingent that had taken two Salgótarján engineers to the outskirts of the village of Hugyag, where they were tortured and killed on December 13, $1956 .{ }^{3}$

However, no one had ever shared this information with me in Varsány, I had no opportunity to check it, thus I do not know whether or not it was true. Such sensitive,

\footnotetext{
${ }^{3}$ On the role of Rudolf Hadady and Lajos Hargitai, their activities during and after the 1956 revolution, and their deaths, see: Á. VARGA 1996:51.
} 
personal data justified the omission of personal names in the Varsány publications, as is typically the case in socioanthropological publications, even when the locals would have preferred otherwise, as illustrated by a book of local history published by the local municipality (HAUSEL 2000).

\section{RITITI}

Coffee production and coffee exports, which are extremely important for the Kenyan economy, fell sharply following the collapse of the International Coffee Agreement in 1989. In order to explore what was happening in the various coffee-growing areas and the coffee industry as a whole, the Institut Français de Recherche en Afrique (Nairobi) launched an interdisciplinary research programme, as part of which I spent three months in Kenya in 1993, and another month in 1995. For two months of the first period and for the whole month of the second period, I was in Nyeri District, mainly in Rititi. ${ }^{4}$

Within the general thematic programme, I was free to define my own research scheme, as well as the location in which I carried out my fieldwork within Nyeri District. It was clear that the decline in coffee production was related to the fall in the selling price of coffee, although the economic considerations and the technical realization of the scaling down of production on the plantations of small farmers, where the cutting down of existing coffee plants was banned by the state, was the topic and primary purpose of my study.

During this research, as in Varsány, I relied mainly on participant observation and in-depth conversations in order to gain an understanding of people's motivations, but I was aware that the time was far shorter, while I also had to manage without the historical sources and statistics that were available in Hungary. Encouraged by the work of Michael Chibnik in Belize, who - using statistical analyses undertaken in two villages that differed in terms of access to the market and certain other features - attempted to clarify why many people chose wage labour rather than growing cash crops (CHIBNIK 1980), I tried to expand my research material with a similar statistical survey. I therefore compiled a questionnaire to investigate the composition of individual families, the educational levels of family members, their jobs, their property relations, the division of labour, land-use methods, coffee-growing procedures, incomes from different activities, knowledge of the coffee industry as a whole, and plans for their own economic future.

I distributed 207 copies of the questionnaire to local teachers - after completing one with a family from Rititi - 132 to the villages surrounding the Rititi coffee factory, and 75 further afield, in the neighbourhood of Mukurweini, a small town with a significant coffee-production cooperative, $20 \mathrm{~km}$ away. 164 questionnaires were returned, which is a very good proportion. I explained to the teachers what to ask, and how, and the teachers were given just five questionnaires each, so that they could make a really comprehensive record, rather than doing a slapdash job. Naturally, I paid them for their work, and in every participating school I gave a presentation on Hungary to the teachers and students.

\footnotetext{
${ }^{4}$ For this opportunity, I would here like to express my gratitude to Mme Le Cour Grandmaison, the then director of the IFRA (Nairobi), for the professional as well as the colleagial help to the staff of the institute, especially to the programme director, geographer Bernhard Calas.
} 
I had already visited the locations before the questionnaires were distributed. In selecting the locations, as well as in the research as a whole, Richard Muriuki Mathenge, who was introduced to me as an interpreter by IFRA staff, was of immense help. In the course of our work, he was not just an interpreter and an assistant, but became a real friend who - during my visit in 1995, when he was working in Nairobi - visited me in Rititi every weekend to help me, without asking for any compensation.

From the central fieldwork station in Rititi, where I lived with Mathenge's family, I often travelled to Ngandu, the local public administrative centre. This meant that I lived with Mathenge's grandmother in a house that had once belonged to Mathenge's father. In the Kikuyu villages, where polygyny was permitted, and where it was more common at one time, each wife had a separate house, as did her husband. Mathenge's grandmother had had her own house, but it was now in such poor condition that she had moved into the house of her late son, and since, at the age of seventy-seven, she was no longer subject to female norms of behaviour, she was able to live in the house with me, while I was not permitted to enter the home of Mathenge's mother, who cooked for me, unless another family member was present.

I lived alongside the men, sometimes lending a hand in any jobs that came up, always taking into account the principles of the gender division of labour, and I carried out my own work, observing, conversing, and doing interviews. During the first week, I went to the pub every night with Mathenge so that the men could get to know me, and after that I was comfortable walking around the village even at night, while even the local inhabitants did not dare come and go outside the village. Being able to live with a family was very important, and I came in contact with the extended family, as well as with relatives of Mathenge living in other settlements.

In order to distribute the questionnaires, I rented a car for three days, and I picked up whoever I met on the road, which led to many good relations, since white people do not usually pick up locals in their cars. Also important was the support of one of the village elders, Uncle Wachira, who organized my protection, which I learned about - during a pre-wedding feast to which I was invited - only weeks after my arrival in the village, when I had already interviewed him. ${ }^{5}$ Uncle Wachira really opened up when I returned in 1995, when I caught sight of him at the matatu (a car converted into a minibus) station in Karatina and greeted him by name, telling him that I was going to Rititi the next day. The point here was that not only had I returned, I had also remembered his name. This helped him find his tongue, and he provided me with explanation of an otherwise wellkept secret, about how social peace could be restored after the serious breach of a moral norm, when a husband got both his wife and her sister pregnant (SÁRKÁNY 2006).

In addition to the above methods of data collection, I tried to make use of the data kept at the coffee factories, and I also gathered information from officials working in the cooperatives that play an important role in coffee production and coffee trade. Answers to my research questions were based on the database that I compiled in this way (SÁRKÁNY 2015).

Meanwhile, I was clearly a stranger, the only white person in a place where white people were mostly seen only through the windows of tourist buses. I did not speak

\footnotetext{
${ }^{5}$ On the institution of the village elder, see: SÁRKÁNY 2001b:175.
} 
Kikuyu, I knew only greeting terms and used formulaic phrases to initiate conversations, and only during the second month of my stay did I begin to understand what was being said around me. I carried out the research in English, which was facilitated by the fact that those under the age of 50 spoke excellent English, having learned it from the first grade of elementary school. Nevertheless, the white man was accepted, given a home, and invited to lunch and a wedding reception - I could even have found myself a wife in the nice woman who washed my shirts. On my second trip, a kind acquaintance made sure I had a sapling so that I could plant a tree, as this is the custom on May 1, and he knew I did not have one. But no matter how much I was considered to be "our stranger", it was clear that there were limitations that I was not able to overcome, and there was information that they were reluctant to share even among friends.

One day, I saw a Kikuyu note on the door of the village doctor's office that I did not understand, and Mathenge would not translate it. I insisted until he told me that the announcement was about the upcoming circumcision of boys of the relevant age group at the clinic on Friday. He added that I could not attend, nor could he, and nor could the doctor, as she was a woman. He then told me about his own initiation ceremony.

This, and the similar cases that I have mentioned, convinced me that perfect integration into a different social circle, which I entered as a researcher, was an illusion. There is always one more obstacle that needs to be overcome, and then another. Louis Leakey, a white man who was the most successful in terms of integration in Kikuyu society, who spoke the language perfectly and who had already been initiated and accepted at all levels, was nevertheless still not allowed into the council of homeowners that organized the initiation ceremonies. (LEAKEY 1977:xi).

Obviously, keeping in touch with such a remote field becomes difficult later on. I corresponded with Mathenge for a decade, and I received news from him about Rititi before he left to try his luck in Great Britain. I was able to support him financially in this endeavor, and I also wrote letters of recommendation, but our relationship came to an end after 2004 when I stopped receiving replies to the letters that I sent to his last known addresses. I have no idea what has become of him.

\section{LESSONS LEARNED}

One of the main lessons learned is that, depending on the purpose of the research, different methods of collecting data can be justified in sociocultural anthropology, regional ethnology, native ethnography, etc. Where narrower questions are posed, a simpler, more formalized method of collecting data may be appropriate, while the ethnographer still does not become a mere butterfly collector - as Edmund Leach accused those who obtained their data not by long, painstaking fieldwork and were satisfied with their mere classification (LEACH 1961:3-6) - if the collected data fit into a well-thought-out research process that begins with theoretical considerations and proceeds to the drawing of possible conclusions. The less known the connections one seeks to discover, the more open and diverse the exploration undertaken by the researcher should be.

However, the questions posed may be influenced by several factors, not just interest on the part of the researcher. One such factor might be the time available to the researcher. It can happen that it is not in his power to stay longer, although he hopes 
that his original exploratory collection of data may encourage others to carry out more exhaustive investigations. Another case is when the ephemeral nature of the phenomena justify their mere recording, in aware of the fact that their interpretation is bound to leave some questions open. I experienced this in my own work, and was thus able to apply the routine acquired during data collection for the Atlas of Hungarian Folk Culture in my explorations of relationship terminology (SÁRKÁNY 2016:129-165), and during the East African trip for the Hungarian Scientific African Expedition of 1987-88, which - in addition to the collecting of objects and recording of impressions - also provided materials for the eventual publication of a scientific study (SÁRKÁNY 2000a, 2001a).

The kind of fieldwork that makes participant observation possible, requiring a position within a multitude of human relationships, and which necessarily requires a longer time than other techniques for the collection of data, is appropriate for exploring the more complex relationships resulting from openness to the unknown, for which the leavening effect of theoretical inspiration is essential. More importantly, it can and should be combined with other, sometimes simple methods of data collection, if the occasion arises, since the comparison of data from various sources can reinforce their promotion as fact, and their organization into processes can provide an opportunity to demonstrate causal relationships. It is important to emphasize that people's ideas are revealed not only during conversations, by means of their communication, but also through other data that are created as a result of their decisions, as I experienced in Varsány and Rititi.

Long-term stationary fieldwork has another benefit: the researcher may notice phenomena that are independent of the original research goal. This was the case in Varsány, although I declined to investigate them more thoroughly at the time, since, due to the division of tasks, others were dealing more extensively with the respective phenomena in the context of their own research. During the second study, however, I decided to publish my thoughts concerning the values of, and the relationships between, generations and genders that went beyond my own reseach topic (SÁRKÁNY 2016:303313). In Rititi, where I worked alone, the many encounters and evening conversations brought up information, some of which I considered worthwhile to share, although, due to the shortness of the time I spent there and the pressure to achieve my main research goal, I was able to clarify to different extents and depths how this information related to other components of social existence and culture (SÁRKÁNY 1999; 2000b; 2001b; 2007).

In connection with my stationary fieldwork, I have mentioned genuine friendships, which I considered essential to establish. After all, the researcher is in the field with his or her own personality and is assessed as a social person (BoND 1990:281), which can either help or hinder the achievement of his or her research goals. From the researcher's perspective, those who do not strive to create relationships with an emotional content deprive themselves of the opportunity for their fieldwork to become a profound human experience and a part of their lives.

\section{LASTLY}

There are some important works that provide information on best procedures of collecting data in the field, some with demands that are virtually unfulfillable from any point of view (e.g. Werner - Schoepfle 1987). These are useful in order to widen the 
researcher's methodological repertoire, since fieldwork, whether it be simple collection of data or multi-faceted, long-term stationary fieldwork, requires ingenuity and creativity, which cannot be avoided through the application of a schematic formula. We should not forget Berreman's warning that a research technique should not be used for its own sake: "obviously, a technique need not preclude other techniques and need not obscure goals", and "those who become enamored of a technique often lose sight of what their technique is for," which also recalls the observation of the remarkable sociologist Peter Berger, that "in science as in love, an overemphasis on technique is quite likely to lead to impotence" (BERREMAN 1966:349).

\section{REFERENCES CITED}

Á. VARGA, László (ed.)

19961956 Nógrád Megyei Kronológiája és Adattára. (A forradalom eseményei és aktív szereplöi a megyében.) [Chronology and Repository of 1956 in Nógrád County. Events and Active Participants of the Revolution in the County]. Salgótarján: Nógrád Megyei Levéltár.

BARABÁs, Jenő

1963 Kartográfiai módszer a néprajzban [Cartographic Method in Ethnography]. Budapest: Akadémiai Kiadó.

1990 Válaszút vagy útvesztő. Észrevételek Niedermüller Péter cikkéhez [Crossroads or a Maze? Observations on an Article by Péter Niedermüller]. BUKSZ 2(1):3-5.

BARABÁs, Jenő (ed.)

1987-1992 Magyar Néprajzi Atlasz [Atlas of Hungarian Folk Culture]. I-IX. Budapest: Akadémiai Kiadó.

BARABÁs, Jenő et al.

1959 A Magyar Néprajzi Atlasz kérdöive. Gyüjtési Útmutató [Questionnaire for the Atlas of Hungarian Folk Culture. Guidelines for collecting data]. Budapest, no publisher.

Beauvoir, Simone de

1977 Old Age. (Translated by Patrick O’Brian.) Harmondsworth: Penguin Books.

Bell, Colin - Newby, Howard

1971 Community Studies. London: George Allen \& Unwin.

Berreman, Gerald D.

1966 Anemic and Emetic Analysis in Social Anthropology. American Anthropologist $68: 346-354$.

BIRó, Hajnalka

2006 A falusi lakóház épitkezéskultúrájának változása a XX. században Varsány példáján [Changes in Vernacular Architecture in the 20th Century as Seen in Varsány]. Thesis. ELTE BTK Néprajzi Intézet (manuscript).

BoDrogi, Tibor (ed.)

1978 Varsány. Tanulmányok egy észak-magyarországi falu társadalomnéprajzához [Varsány. Studies for the Social Anthropology of a Village in Northern Hungary]. Budapest: Akadémiai Kiadó. 
Bond, George C.

1990 Fieldnotes: Research in Past Occurences. In SAnjex, R. (ed.) Fieldnotes: the Makings of Anthropology, 273-289. Ithaca: Cornell University Press.

CHIBNIK, Michael

1980 The Statistical Behavior Approach: the Choice between Wage Labor and Cash Cropping in Rural Belize. In Barlett, Peggy F. (ed.) Agricultural Decision Making, 87-114. New York: Academic Press.

Cseh-Szombathy, László - Ferge, Zsuzsa (eds.)

1968 A szociológiai felvétel módszerei [Methods of Collecting Data in Sociology]. Budapest: Közgazdasági és Jogi Könyvkiadó.

Driessen, Henk - JANSEN, Willy

2013 The Hard Work of Small Talk in Ethnographic Fieldwork. Journal of Anthropological Research 69:249-263.

Gergely, Katalin

2000 Hagyományőrző palóc falu [A Traditionalist Palóc Village]. In PÁLMÁNY, Béla (ed.) Varsány. Egy palóc falu évezrede, 191-222. Varsány: Varsány Község Önkormányzata.

GraEBNER, Fritz

1911 Methode der Ethnologie. Heidelberg, Carl Winter's Universitätsbuchhandlung. Hann, Chris - SÁRKÁNY, Mihály

2003 The Great Transformation in Rural Hungary: Property, Life Strategies, and Living Standards. In Hann, Chris and the "Property Relations" Group: The Postsocialist Agrarian Question, 117-141. Münster: LIT Verlag.

Hausel, Sándor

2000 A falu a polgári forradalomtól a polgári rendszerváltozásig [The Village from the Bourgeois Revolution to the Bourgeois Change of Regime]. In PÁLMÁNY, Béla (ed.) Varsány. Egy palóc falu évezrede, 107-190. Varsány, Varsány Község Önkormányzata.

Hollos, Marida - Maday, Bela C. (eds.)

1983 New Hungarian Peasants: An East-Central European Experience with Collectivization. New York: Brooklyn University Press.

HoppáL, Mihály

1977 A tér, a közösség és a kommunikáció [Space, Community and Communication]. Budapest: Tömegkommunikációs Kutatóközpont.

JÁvor, Kata

1998 A nemi sztereotípiák továbbélése és a szocializációs modell alakulása a nemi szerepre nevelésben [Survival of Gender Stereotypes and the Development of the Socialization Model in the Formation of Gender Roles]. Népi Kultúra Népi Társadalom XIX:155-172.

2004 A hálókamrától a franciaágyig. A fiatalság élete Varsányban 1971-2004 között [From Bedchamber to French Bed. The Life of Youth in Varsány 1971-2004]. In Borsos, Balázs - Szarvas, Zsuzsa - Vargyas, Gábor (eds.) Fehéren, feketén - Varsánytól Rititiig, 467-478. Budapest: L'Harmattan.

2006 Rôles sexués à Varsány (1971-2004): entre tradition et modernité. Ethnologie Française 36:273-282. 
2007 Varsány értékrendjének és társadalmi intézményrendszerének változása 30 év tükrében [Changes of Value Systems and Social Institutions in Varsány (1971-2004)]. Ethno-Lore XXIV:112-151.

Kardos, Ferenc

2005 Kutatás közben. A varsányi cigányok a mezőgazdaságban a 20. század második felében. [Research in Progress. Gypsies of Varsány in Agriculture in the Second Part of the 20 ${ }^{\text {th }}$ Century]. In Schwarcz, Gyöngyi - Szarvas, Zsuzsa - SzILÁGYi, Miklós (eds.) Utóparaszti hagyományok és modernizációs törekvések a magyar vidéken, 47-58. Budapest: MTA Néprajzi Kutatóintézet MTA Társadalomkutató Központ.

LEACH, Edmund

1961 Rethinking Anthropology. London: Athlone Press.

LEAKEY, Louis S. B.

1977 The Southern Kikuyu before 1903. Vol. I. London - New York - San Francisco: Academic Press.

MaLinowsKi, Bronislaw

1922 Argonauts of the Western Pacific. London: Routledge \& Kegan Paul.

MÁtÉ, György

2004 Borzag [Sambucus ebulus]. In A. Gergely, András - Kemény, Márton (eds.) Motogoria, 338-348. Budapest: MTA Politikai Tudományok Intézete Könyv Kiadó Kft. - ELTE Kulturális Antropológia Szakcsoport.

MÉszÁros, Csaba - VArgyas, Gábor

2016 Gyüjtés és terepmunka a néprajztudományban [Collecting Data and Fieldwork in Ethnography]. Ethno-Lore XXXIII:9-17.

NAGY, Géza F.

1987 A párválasztás Varsányban [Mate Selection in Varsány]. In KósA, László (ed.) Népi Kultúra - Népi Társadalom XIV:399-428.

NÉMETH, Krisztina

2015 A terepmunka és a kutatói pozíció reflektálása mint az értelmezés rejtett eröforrása [Reflection on Fieldwork and the Position of the Researcher as a Hidden Resource for Interpretation]. In VIRÁG, Tünde (ed.) Törésvonalak, 27-44. Budapest: Argumentum.

PalÁDI-Kovács, Attila

1996 Ethnic Traditions, Classes and Communities in Hungary. Budapest: Institute of Ethnology, Hungarian Academy of Sciences.

2017 A Magyar Néprajzi Atlasz kérdőíve, gyüjtési munkálatai és adatbázisa [The Qustionnaires, Fieldwork and Database of the Atlas of Hungarian Folk Culture]. Ethno-Lore XXXIV:15-30.

SÁRKÁNY, Mihály

1989 Documents of Land Redistribution as Ethnographic Sources. In YLIAHO, Timo (ed.) The Third Finnish-Hungarian Symposium on Ethnology in Konnevesi 20-25 - 8. 1989. I. Historical Sources. Ethnos 8(1):119-124.

1999 'Igaz' történetek kikuju boszorkányokról [“True” Stories of Kikuyu Sorcerers]. In BenEDEK, Katalin - CsONKA-TAKÁcs, Eszter (eds.) Démonikus és szakrális világok határán. Mentalitástörténeti tanulmányok Pócs Éva 60. születésnapjára 95-102. Budapest: MTA Néprajzi Kutatóintézet. 
2000a Eine Twa-Keramik. In Nagy, Ilona - Verebélyi, Kincső (eds.) Folklore in 2000. Voces amicorum Guilhelmo Voigt sexagenario, 473-483. Budapest: Loránd Eötvös University of Sciences.

2000b Körbe forog a kerék, avagy mivel játszanak a kelet-afrikai gyermekek [The Wheel Goes Around, or What Children Play with in East-Africa]. Kultúra és Közösség 2000(4)-2001(1):109-118.

2001a Az elmolók. Egy etnikum reorganizációja a Turkana-tó mellett [The Elmolo. Reorganization of an Ethnic Group at Lake Turkana]. Népi Kultúra - Népi Társadalom XX:301-315.

2001b Kávé és földtulajdon a kikujuknál [Coffee and Land Ownership among the Kikuyu]. In Hála, József - Szarvas, Zsuzsa - Szilágyi, Miklós (eds.) Számadó. Tanulmányok Paládi-Kovács Attila tiszteletére, 171-177. Budapest: MTA Néprajzi Kutatóintézete.

2005 Restudy of Varsány: Entrepreneurs and Property in Rural Hungary after 1989. In Skalnik, Peter (ed.) Anthropology of Europe. Teaching and Research, 143151. Prague: Set Out.

2006 Emberi botlások és a társadalmi rend helyreállítása - egy rendhagyó kikuju házasság esete [Human Slip-Ups and the Restoration of the Social Order the Case of an Unusual Kikuyu Marriage]. In Sebestyén, Éva - Szombathy, Zoltán - TARrósy, István (eds.) Harambee. Tanulmányok Füssi Nagy Géza 60. születésnapjára, 330-337. Pécs: Publikon Könyvek - ELTE Afrikanisztikai Oktatási Program.

2007 A történelem mitikus magyarázata és szóban rögzítése a kikuju hagyományban [The Mythical Interpretation and Oral Recording of History in Kikuyu Tradition]. In SzemerkénYI, Ágnes (ed.) Folklór és történelem, 323-335. Budapest: Akadémiai Kiadó.

2013 Interests, Resources and Status: The Distribution of Income, Work and Authority in the Family in a Northern Hungarian Village. Acta Ethnographica Hungarica 58:87-96.

2015 Hogyan termelnek és nem termelnek kávét kikuju kisbirtokosok [Coffee as a Challenge for the Kikuyu Smallholder: To Produce or Not To Produce?]. In JAKAB, Albert Zsolt - KindA, István (eds.) Aranykapu. Tanulmányok Pozsony Ferenc tiszteletére, 607-617. Kolozsvár: Kriza János Néprajzi Társaság Szabadtéri Néprajzi Múzeum - Székely Nemzeti Múzeum.

2016 Társadalom és gazdaság [Society and Economy]. Edited by Gábor VARGYAS. Budapest: L'Harmattan.

SzABÓ, Piroska

2006a A kommunikáció változása a vidéki Magyarországon a telefónia általánossá válása nyomán [Change of Communication in the Hungarian Countryside Subsequent to the General Use of the Telephone]. Jelkép 2006(1):47-55.

2006b Kisgazdaságok Varsányban [Smallholders in Varsány]. Ethno-Lore XXIII:327-341.

Werner, Oswald - Schoepfle, G. Mark

1987 Systematic Fieldwork I-II. Newbury Park - Beverly Hills - London - New Delhi: Sage Publications. 
WoLf, Eric R.

2001 Pathways of Power. Berkeley - Los Angeles - London: University of California Press.

Mihály Sárkány (b. 1944) is senior honoris causa at the Institute of Ethnology of the $\mathrm{RCH}$ of the Hungarian Academy of Sciences, and retired associate professor in the Department of Cultural Anthropology, ELTE University, Budapest. His main research fields are economic anthropology, the history and theories of sociocultural anthropology, and the transformation of rural economy and society in Hungary and Africa. He has carried out long-term field research in Hungary and Kenya, and extensive fieldwork in Romania, Tanzania, Rwanda, Burundi and the Democratic Republic of Congo. E-mail: sarkany.mihaly@btk.mta.hu 